\title{
The Opportunities to Obtain Traditional Fisheries Rights for Aceh Traditional Fishermen
}

\author{
Sulaiman ${ }^{1 *}$, M. Adli ${ }^{1}$, Kamaruzzaman Bustamam-Ahmad $^{2}$, Teuku Muttaqin \\ Mansur $^{1}$, Enzus Tinianus ${ }^{1}$, Lia Sautunnida ${ }^{1}$, Mukhlisuddin Ilyas ${ }^{3}$ \\ ${ }^{1}$ Faculty of Law Universitas Syiah Kuala Banda Aceh, Indonesia \\ ${ }^{2}$ Faculty of Sharia and Law State Islamic University Ar-Raniry, Banda Aceh, Indonesia \\ ${ }^{3}$ Bandar Institute, Banda Aceh, Indonesia \\ ${ }^{*}$ Corresponding author. Email: sulaiman.fh@unsyiah.ac.id
}

\begin{abstract}
This paper aims to give the reasons why Acehnese traditional fishermen crossed the territorial borders of the country so that they were arrested in neighboring countries, as well as the opportunities for Acehnese traditional fishermen who sail in the west part of Indonesian water areas to get their traditional fisheries rights. This study applies the socio-legal method. Data were collected by conducting in-depth interviews with traditional fishermen who have been arrested in several neighboring countries, and the authorized officials (in the maritime and fisheries sector), as well as the academicians in the law of the sea, to get an analysis regarding the opportunities for traditional fisheries rights. To complement the main data, this study also conducted document tracing of cases where Aceh traditional fishermen have crossed the borders and being caught in other countries. All data were analyzed qualitatively. This research found that in the last ten years, more than 400 cases of Acehnese traditional fishermen were caught for crossing the territorial borders of other countries. In 2020, 135 fishermen are still abroad, 69 in India, 57 in Thailand and 9 in Myanmar. Especially in Thailand, as many as 51 fishermen received the king's pardon and were able to return to Indonesia. From these numbers, not all are included in the category of traditional fishermen, and some of them are deliberately involved in fishing that violates the provisions of other countries. Especially for traditional fishermen, there is a history of fishing that was conducted in locations that are no longer part of Indonesia's territorial waters. Since 2005 Panglima Laot Aceh (the commander of the sea) has asked the Government to fight for traditional fishing rights for Acehnese fishermen in the west part of Indonesia water areas, by having an agreement with the Indian state, the above idea related to the statement in Article 51 of the United Nation Convention Law on the Sea (UNCLOS) 1982. Traditional fisheries rights can be obtained by conducting bilateral talks, preceded by a request from one country, then conducting talks and agreements, the agreement of which cannot be transferred to other countries or other citizens. However, this option has not been made. Another thing that becomes a challenge is Indian water areas, which are directly adjacent to the west part of Indonesian water areas, used by India as marine protected areas.
\end{abstract}

Keywords: traditional fisheries rights, UNCLOS 1982, traditional fishermen, aceh fishermen.

\section{INTRODUCTION}

This paper aims to answer three problems: (1) what caused Aceh traditional fishermen to cross the country's territorial borders so that they were arrested in neighboring countries? (2) what opportunities are there for traditional fishermen in Aceh sailing the sea in the west part of Indonesia water areas?
The above problems are very important to be answered, where the number of Aceh fishermen who cross the boundary of other countries keeps increasing. On 29 September 2020, as many as 51 Aceh fishermen who were arrested by Thailand authorities were returned to Indonesia [1]. These Aceh fishermen received forgiveness from the King of Thailand. Apart from these fishermen, there are 85 fishermen abroad: 69 in India, 6 in Thailand, and 9 in Myanmar [2]. The case of the arrest of Aceh 
fishermen abroad is not new. Early January 2012, there were Aceh fishermen arrested in India. These fishermen are considered to have crossed the territory of India. However, with the "approach" of the state authorities and successfully proving that they were stranded, the three fishermen were released and returned by the KRI warship. In addition, at the end of 2012, some of other fishermen were again arrested by the Indian authorities [3].

Based on data released by Panglima Laot Aceh, in 2009, 19 Aceh fishermen were stranded. Meanwhile, in 200826 fishermen had the same fate. The total number in the last three years has reached 58 fishermen were missing, and 53 have returned to Aceh [4]. In hindsight, the missing fishermen have occurred a long time ago. In mid-February 2008, five Aceh fishermen were missing and estimated to be in the water areas of Nicobar Islands [5]. In mid-January 2008, five fishermen were adrift in the Economy Exclusive Zone (EEZ) towards India and were found by another boat passing by. They have been at sea since early December 2007, but there the engine was damaged. Cases happened in 2006, as many as six Aceh fishermen were arrested in India, they came from Banda Aceh, Sigli, and Meulaboh who were arrested due to entering Indian territory. At the end of 2007, as many as 15 Aceh fishermen were also reported missing until finally as many as 10 Aceh fishermen returned safely [6].

In 1995-1999, there were several cases that had not been tracked. During 2000-2001, Aceh fishermen were arrested in India reached 150 people. Various arrest cases, according to Indian authorities, were because they have crossed the line of Indian territory and are accused of stealing fish, so they have to undergo punishment while Indonesia cannot interfere with Indian sovereignty. According to data from Panglima Laot Aceh, from all countries, including Burma, Malaysia, Thailand, the Philippines, Sri Lanka, Aceh fishermen that were arrested in 2001 reached more than 300 . The number of vessels caught was around 32. Usually, the case of fishermen who are missing is only known after a report from the family or fisherman. Panglima Laot Aceh or the media then communicated with the embassy to ask for clarification and request information about the legal process in the concerned country. Panglima Laot himself claimed that they were traditional fishermen, and accidentally entered the water areas of other countries.

Panglima Laot Aceh once "asked for an explanation of the territorial boundaries of the Aceh fishing customary community, which are known to be 200 nautical miles from the baseline. Panglima Laot asked for the assertiveness of the water areas between the two countries [7]. Based on fishermen's understanding, referring to the EEZ which is 200 miles away, the Nicobar and Andaman Islands are part of Indonesia's territory. "In addition, one of the recommendations of Meusapat Council of Panglima Laot Aceh on 9-11 December 2005 that is "Requesting the Aceh Provincial Government and the Central Government to be able to fight for the traditional fishing rights of Aceh fishermen (traditional fisheries rights) by having an agreement with India and Thailand, in accordance with Article 51 UNCLOS 1982".

\section{RESEARCH METHOD}

Research on this theme is important because so far many Acehnese fishermen have been stranded in other countries. Some of the fishermen were accidentally stranded. This research applies the socio-legal method and relies on the results of in-depth interviews with fishermen that have been arrested in some other countries, and the authorized officials (in the maritime and fisheries sector), as well as academicians in the law of the sea to obtain an analysis towards the opportunity of traditional fisheries rights. Interviews are very important in getting the main data in this study [8]. Legal materials used are Law Number 5 Year 1983 on Indonesia's Economic Exclusive Zone, Law Number 45 Year 2009 on Amendment to Law Number 31 Year 2004 concerning Fisheries, Article 51 UNCLOS 1982, and Qanun (Aceh regulation) No. 7 Year 2010 on Fisheries. To complement the main data, this study also conducted document tracing of cases where Aceh fishermen were arrested in some countries for crossing borders. All data were analyzed qualitatively.

\section{FINDINGS AND DISCUSSION}

\subsection{State Boundary and Traditional Fisheries Rights}

On January 21, the Royal Thai Navy (RTN) arrested 33 Aceh fishermen on two sailing motorboats. They are suspected of violating the Fisheries Law that they have fishing gear in the form of a trawl and navigation equipment on board. After the arrests, the two ships were taken to the RTN headquarters at the Thap Lamu base, Phang Ngah Province. Two years earlier, in November 2018, 16 fishermen from East Aceh were arrested. They are accused of illegally entering and fishing in the water areas of Kawthaung, Myanmar. After had been prisoned in Myanmar, 14 of the 16 fishermen were successfully sent home. Meanwhile, the ship's captain must undergo a legal process on charges of illegal fishing. Another fisherman died because he drowned during the arrest. In addition, on 6 February 2018, the Myanmar Navy again arrested 23 Indonesian fishermen from East Aceh, near Zardatgyi Island, 
Kawthoung Township, Taninthayi. They were arrested while a Myanmar naval ship was on patrol for allegedly fishing illegally.

Based on interviews with fishermen, the reasons for the alleged illegal fishing in other countries are most predominantly imposed on them. Based on Panglima Laot's data stated another reason, that is the weak knowledge of Aceh fishermen about the boundaries of the sea area and not being equipped with sophisticated navigation tools. As a result, fishermen often cross water boundaries while fishing.

Based on interviews, there were some fishermen who have suspected of committing fishing theft. In addition, not all are included in the category of traditional fishermen, and some are deliberately involved in fishing that violates the provisions of other countries. Especially for traditional fishermen, there is a history of fishing that was conducted in locations that are no longer part of Indonesia's territorial water areas. Especially for traditional fishermen, legal protection must be obtained fairly.

In international law of the sea, as well as in statutory regulations and customary law of the sea, there is no explicitly stated about traditional fisheries rights. The term "traditional fisheries rights" is not included in Law Number 5 Year 1983 concerning Indonesia's Economic Exclusive Zone (EEZ) nor in Law Number 45 Year 2009 on Amendment to Law Number 31 Year 2004 concerning Fisheries.

Article 51 UNCLOS 1982, it is regulated regarding the treatment of archipelagic countries, the state respects agreements with other countries and must recognize traditional fisheries rights. This article notes that these rights are at the request of a country and are regulated by bilateral agreements and may not be shared with third countries or their citizens. There are several notes on the applicability of Article 51 UNCLOS 1982. Article 51 is included in Chapter IV "Archipelago States“. The clause contained in Article 51 reduces the rights of an archipelago state. Like it or not, as "bargaining" for the archipelagic state regime to be accepted by the countries discussing the Law of the Sea Convention III, archipelagic countries such as Indonesia, the Philippines and Mauritius "have to" accept the provisions of Article 51.

If we read carefully the provisions contained in Article 51 UNCLOS, it can be noted that this provision is the obligation of an archipelagic state to accept proposals/requests from other countries to be granted traditional fisheries rights for their fishermen. Until now, Article 51 is still debated. There are several odd things and inconsistencies in Indonesia, such as: First, the case of the Philippines' request to be granted their traditional fisheries rights in the North
Sulawesi sea, Indonesia refused. Second, Indonesia instead asked Australia for traditional fisheries rights for Indonesian fishermen, Australia responded. In fact, Australia is not an archipelagic country.

In addition, in the explanation of Article 9 paragraph (1) of Law No. 6 Year 1996, states: "Even though Indonesia has full sovereignty in its archipelagic water areas, Indonesia must respect agreements or agreements made with other countries regarding the legal use of parts of its archipelagic water areas for the implementation of traditional fisheries rights, rights of access and communication among neighboring countries directly adjacent to, installation, maintenance, and replacement of cables on the seabed by states".

Article 1 paragraph (1) Law No. 6 Year 1996, what is meant by an archipelagic state is "a country that entirely consists of one or more islands and can include other islands." Article 2 clearly states that Indonesia is an archipelagic country. Based on UNCLOS 1982 or KLH 1982, it can be seen that in the context of Indonesia, with the recognition of the principle of an archipelagic state, the water areas that were formerly part of the high seas have now become "archipelagic waters" which means the territorial waters of the Republic of Indonesia.

In the provisions of Article 51 UNCLOS 1982, it can be concluded that not only respecting existing international treaties, the archipelagic state is also obliged to respect the traditional fisheries rights and other legitimate activities of neighboring countries which are directly adjacent, as well as submarine cables that already exist in certain parts of archipelagic waters which were formerly the high seas. These traditional fishing rights and other legitimate activities may not be transferred to or shared with third countries or their citizens. According to Customary Law of the Sea, the concept and regulation of traditional fisheries rights issues are completely not stated (it can be seen in various decisions of Panglima Laot) [9].

The term traditional fisheries rights and how they are implemented should be referred to Article 74 UNCLOS 1982. It is stated that the division of the sea for coastal areas which facing each other and side by side is in accordance with Article 38 of the International Court of Justice Statute. Furthermore, Article 38 of the International Court of Justice Statute contains the sources of international law, including: (1) International conventions, both general and specific; (2) international customs; (3) general principles of law recognized by civilized countries; (4) judicial decisions and opinions of experts who have recognized their expertise (teachings of the most 
highly qualified publicist) that are an additional source of International Law.

Article 2 Year 1969 on Vienna Convention, stated that an International Treaty is "an agreement made between countries in writing, and is governed by International Law, whether in a single instrument or two or more related instruments and whatever name is given to it."

Article 1 paragraph (3) of Law No. 37 Year 1999, stated that "International treaties are agreements in any form and designation, which are governed by International Law and made in writing by the Government of the Republic of Indonesia with one or more countries, international organizations or other international legal subjects, and raises rights and obligations to Government of the Republic of Indonesia which is public law."

In Article 24 paragraph (1) Law No. 6 Year 1996, stipulated that "the enforcement of sovereignty and law in Indonesian water areas, the air space above it, the seabed and the land beneath it including the natural resources contained therein and sanctions for violations, are carried out in accordance with the provisions of other international law conventions, and applicable statutory regulations. As already mentioned above, that Law No. 17 Year 1985 stated the problem of the recognition of the principle of an archipelagic state, then the water areas that were once part of the high seas are now "archipelagic waters" which means the territorial waters of the Republic of Indonesia.

The implication as stated in UNCLOS 1982 that traditional fisheries rights are respected with several important requirements (Article 51), that are: (a) a request from one of the countries, (b) regulated by bilateral agreement, (c) the rights is non-transferable to third countries and their citizens. Referring to Article 57 KHL, Indonesia's EEZ is no more than 200 miles away. The KHL Article states that the coastal state "can take necessary actions, such as inspecting, arresting ships and conducting judicial proceedings against the ships that violate the provisions made by the coastal state."

\subsection{Obtaining Traditional Fisheries Rights}

In the case where Aceh fishermen were arrested in India, the regional authorities suspect that Aceh fishermen stole fish in their water areas. Regarding this claim, there are three versions of the answer: First, The acknowledgment of Panglima Laot Aceh about some fishermen who entered Indian territory, but they were not on purpose entered Indian territory. Second, the fishermen's admission that there were Aceh fishermen who did not know their boundaries and were arrested. Third, the recognition of sharkseeking fishermen, that some of them know the boundaries and may already understand the exact hours of Indian marine police patrols, they are not afraid to enter Indian territory because they need to chase sharks.

On various occasions, Panglima Laot stated that all fishermen arrested by the Indian coastal patrols are traditional fishermen who are also the breadwinner of the family [10]. Based on interviews, this claim is a very strategic effort to support the existence of traditional fisheries rights that have existed for a long time at the sea borders of the two countries. The problem that arises then is the criteria for traditional fishermen and the behavior of the fishermen who were arrested. The fact that almost no Aceh fishermen were released before the detention process took place, it seems that the Indian authorities also have proof of their claim. After that there is a question about the fishermen that have been caught, it is generally revealed that the average shark hunter is crossing the state border. Sometimes ships are pulled by currents. There are also claims that the Indian patrol has crossed the line, even though it had not before.

This problem is a determining factor whether or not it is easy to obtain traditional fisheries rights [11]. In addition, that traditional fisheries rights are possible, there is a possibility that these rights are not recognized because they are considered fishermen who do not meet a certain level of quality, which according to them are no longer included as traditional fishermen, especially in statistical figures measured by gross tone (GT). Referring to statutory regulations, the term "traditional fishermen" is found in Qanun No. 16 Year 2002. In Article 1 paragraph (24), it is stated that "Traditional fishermen are fishermen who depend on their entire life from fishing activities, carried out from generation to generation by using simple fishing gear." This concept was later used in Qanun No. 7 Year 2010 on Fisheries. In the amended Fisheries Law, this concept is not found, except in the Law on Protection of Fishermen.

From the above description, it is clear that traditional fishermen are measured by the income obtained from fishing activities, and its activity is carried out using simple fishing gear. In doing their activities, traditional fishermen are not obliged to have a fishery business license. Traditional fishermen in Aceh are an important component in fisheries management efforts in Aceh. Fishery resources are managed to achieve the maximum benefit for the community, especially fishermen. This is also intended as an effort to accelerate development in the regions. This hope is in line with Article 33 paragraph (3) of the 1945 Constitution which aims the implementation of state control over marine and fishery resources to be directed towards achieving the 
greatest possible benefit for the prosperity of the people.

Previous Fisheries Qanun, specifically Article 16 Qanun No. 16 Year 2002, states that "the Provincial Government encourages, mobilizes, assists, empowers and protects traditional fisheries businesses and protects small-scale fish cultivators, especially through cooperatives, traditional institutions, and other forms of economic and fisherman empowerment." In contrast to Qanun No. 16 Year 2002 which expressly uses the term "traditional fishermen", Law No. 45 Year 2009 uses the term "small fishermen". In Article 1 paragraph (11) it is stated that "Small fishermen are people whose livelihoods are fishing to meet their daily needs using fishing boats with a maximum size of five Gross Tons." Article 61 paragraph (1) states "Small fishermen are free to catch fish throughout the Indonesian Fish Cultivation Territory."

Regarding the large number of Aceh traditional fishermen who were stranded in other countries, Panglima Laot Aceh once recommended that the Aceh Regional Government to have MoU with an archipelago country close to Indonesia, presumably this agreement with a concession gives freedom to traditional fishermen who do fishing in the archipelago. However, at that time, the Aceh local government urged traditional fishermen not to do fishing near the territorial boundaries, to avoid being caught by patrols from other countries [12].

Since 2005 Panglima Laot Aceh has asked the Government to fight for traditional fisheries rights in the water areas of the west part of Indonesia, having an agreement with the Indian state, following the provisions of Article 51 of the United Nation Convention Law of the Sea (UNCLOS) 1982. Traditional fisheries rights can be obtained by holding bilateral talks, preceded by a request from one of the countries, then conducting talks and agreements, the agreement that cannot be transferred to other countries or other citizens. However, this option has not been made. Another thing that becomes a challenge is Indian water areas, which are directly adjacent to the west of Indonesian water areas, which India uses as marine protected areas.

Until 2007 Panglima Laot still considered it as a strategic matter to be fought for through cooperation with India. There are two important reasons for it; first, the problem of boundaries that are still not clear for some fishermen, so many fishermen do not understand boundaries. Then the problem regarding the fact that Indonesian fishermen are still traditional in terms of fishing gear. In addition, the Indian patrol itself is a form of upholding their sovereignty. When the case of 80 Aceh fishermen in Port Blair, there were about six important letters from Panglima Laot Aceh, as well as their answers.

First, a letter from Panglima Laot Aceh dated January 30, 2001 to the Indonesian Embassy in New Delhi, "asking for an explanation of the territorial boundaries for the indigenous fishing communities as having been known about 200 EEZ miles." In the Panglima Laot document (2001), it is stated that this institution also "asks for the confirmation of the maritime boundary of the two countries (median line) so that fishermen know clearly because it refers to the EEZ which is 200 miles away, then the Nicobar and Andaman Islands actually enter Indonesia, while if India refers to EEZ, then Rondo Island is part of their territory. If Rondo and Nicobar islands are 60 miles apart, it needs to be divided by 30-30."

Second, in a response letter from the Indonesian Consular in New Delhi, "in terms of boundaries it needs to be discussed in Indonesia, and on the other hand, the Indonesian and Indian Governments need to discuss further to produce a binding decision, but it will take a long time, considering the various technical matters of the two parties, good relations were then offered as an alternative way of looking at these problems at the bilateral level."

Third, in another letter from Panglima Laot Aceh dated February 2, 2001 to the Indonesian Ambassador in New Delhi, it stated that "the fishermen who were arrested are poor traditional fishermen and no one is taking care for their families, the alternative expected is to return the fishermen to their families with a country approach ".

Fourth, another letter was sent by Panglima Laot Aceh to Foreign Minister Alwi Shihab on February 7, 2001, requesting "the return of Acehnese traditional fishermen who were detained in Port Blair, because all of them were from poor families and were unable to pay for repatriation costs". In the letter it is also hoped that "with the case of Acehnese fishermen, urge Indonesia and India to discuss the EEZ issues of the two countries." Panglima Laot was contacted by the Head of the Sub-Division for Consular Affairs at the Indonesian Embassy in New Delhi, Siruaji Raja, stated that he "supports Panglima Laot's proposal for a special MoU for small fishermen from Aceh and India in fishing."

In the Strategic Planning of Panglima Laot Aceh, 9-11 December 2005, Panglima Laot Aceh, illustrated that Aceh fishermen do fishing in the Batu Putih Islands, but many fishermen are caught by the Malaysian and Thai Police. The Indonesian government in 1974 has made an agreement with Australia under which Indonesian traditional fishermen have the right to do fishing. However, 
recently many have been arrested because most of the boats that Australia claims cannot be categorized as traditional fishermen.

The Indonesian state, according to International Law, has the right to enter into agreements on maritime boundaries with neighboring countries. For example, in the case of Batu Putih Island, which is located in the EEZ area adjacent to Thailand and Malaysia, Aceh fishermen have long been fishing there. Now that many Aceh fishermen have been arrested by the Thai government on the island, Panglima laot may ask the central government to have an agreement (traditional fisheries rights) with the country [13].

Regarding the issue of traditional fisheries right itself, one of the factors that is measured is by the presence or absence of the history of Aceh fishermen that have been fishing up to the Nicobar Islands. If there is a history, then it is certain that traditional fisheries rights can be fought for and obtained, but provided there is an agreement between the two countries. Likewise, on the other hand, if Indian fishermen have a history of fishing up to the Indonesian coast, then traditional fisheries rights for them must also be granted (also by agreement between the two countries). Another important note is that traditional fisheries rights are given to traditional fishermen.

In the matter of obtaining traditional fisheries rights, several things are believed to be influencing efforts to fight for traditional fisheries rights for Aceh fishermen. These problems, among others, are in favor of the environment and ecosystem. Fishermen looking for sharks sometimes violate sustainability too. For example, carelessly disposing of sharks that have been taken out fins from them, because it is impossible for the sharks to be transported by their boat to be brought back to Aceh.

Some cases happened to Aceh fishermen, that they really violated the territory. But some fishermen are clever, so when there is a patrol of another country, they throw away the engine oil to make the excuse that they really are stranded. According to the fisherman, these kinds of behavior, if being caught on a foreign patrol, will have a bad impact on fishermen who are actually stranded beyond the territorial borders of other countries due to accidental factors and ignorance and then arrested. From the above description, perhaps the Government has also considered to what extent the efforts to fight for traditional fisheries rights will be carried out. Then from the explanation, at least it has been illustrated that the problem of boundaries and agreements, understandings, agreements, or whatever the name is, there must be efforts from the Government to be realized immediately.

Before discussing fisheries rights, it is necessary to clarify the boundaries in the context of the existence of outer islands in Indonesia as mentioned in Government Regulation No. 78 Year 2005, pays great attention to integrated development in the social, economic, cultural, legal, human resources, defense and security sectors. This means that other countries also think about this kind of interest. In the context of profit calculation, not all traditional fishermen will use the area in the agreement. However, this is important considering that at any time if something happens to them, it can be anticipated.

It must also be considered about regulating rights in an agreement, it is probably to open up equal opportunities to other countries. India itself, if it has a past history of their fishermen who are accustomed to fishing in Aceh water areas, then they must also be given the same rights. It is part of any marine management process. Being an integral part, such as the problem of delimiting, utilizing and maintaining the sea, securing, taking advantage of the role of fishermen and sailors for marine security and maintenance, following new maritime issues (including at the international level, and following the implementation and development of maritime laws and UNCLOS 1982. Ineffective coordination and institutions are one of the obstacles in managing the Indonesian seas with all their full potential.

To support the opportunity to fight for traditional fisheries rights by the Government, it is also important to have an inter-institutional approach between the fishing community of the two countries. It is necessary to obtain the most real conditions regarding the accusation of crossing the line for stealing fish on the one hand and possibly using natural resources with ethics on the other hand. As determined by KHL 1982, the Government makes it possible to fight for traditional fisheries rights, provided that the Government invites Indian authorities to coorporate or understand issues of traditional fisheries right. This cooperation or understanding was possible because in the past Aceh fishermen were used to fishing in these water areas. In addition, it must be an important note that if Aceh fishermen can get traditional fisheries rights, then these rights cannot be transferred to other countries or their citizens.

\section{CONCLUSION}

Many Aceh fishermen were arrested in several countries for crossing the line territories of other countries. From the cases that occurred, not all of them fall into the category of traditional fishermen, and some of them are deliberately involved in fishing 
that violates the provisions of other countries. Especially for traditional fishermen, there is a history of fishing that was conducted in locations that are no longer part of Indonesia's territorial waters.

Since 2005 Panglima Laot Aceh has asked the Government to fight for traditional fisheries rights for Aceh fishermen in the water areas in the west part of Indonesia, by entering into an agreement with the Indian state, in accordance with the provisions of Article 51 of the United Nation Convention Law on the Sea (UNCLOS) 1982. Traditional fisheries rights can be obtained by holding bilateral talks, preceded by a request from one of the countries, then conducting talks and agreements, the agreement that cannot be transferred to other countries or other citizens. However, this option has not been made. Another thing that becomes a challenge is Indian water areas, which are directly adjacent to the west part of Indonesian water areas, which India uses as marine protected areas.

The government is expected to do advocacy for fishermen stranded in other countries.

\section{REFERENCES}

[1] Serambi Indonesia, September 29, 2020.

[2] Serambi Indonesia, September 12, 2020.

[3] News Detik, March 16, 2013.

[4] Panglima Laot, Document of Panglima Laot, January 19. 2010..

[5] Serambi Indonesia, February 22, 2008.

[6] Serambi Indonesia, January 16, 2008.

[7] Letter of Panglima Laot Aceh to RI Embassy in New Delhi), January 30, 2001.

[8] Sulaiman, "Paradigma dalam Penelitian Hukum", Kanun Jurnal Ilmu Hukum, vol. 20, no. 2, p. 255-272, 2018.

[9] M. A. Abdullah, A. Arifin, \& S. Tripa, "Panglima laot: his legacy and role in converning marine resource in Aceh, Indonesia", SHS Web 45, p. 06-30, 2018.

[10] Serambi Indonesia, January 22, 2008.

[11] E. Warassih, S. Sulaiman, D. Rahayu, "Sustainable fishery campaign by small-scale fishers: A case study on law protection on small-scale fishers in Morodemak Village, Demak District, Central Java Province, Indonesia", Environmental Justice, vol. 11, no. 3, p. 114-117, 2018.

[12] Serambi Indonesia, February 24, 2001.

[13] K. Bustamam-Ahmad, "A Study of Panglima La'ōt: An 'Adat Institution in Aceh", AlJami'ah, vol. 55, no. 1, p. 155-188, 2017. 